\title{
Strategies of Successfully Managing Personal Finances for System Excellence
}

\author{
Ridwan, Sukarman, E. Laxmi Lydia, K. Shankar, Phong Thanh Nguyen
}

\begin{abstract}
Managing the money, saving and investing terms are come in to Personal finance. The term Personal finance includes mortgages, estate planning, investments, budgeting, insurance, banking and tax planning. The complete industry that provide any kind of financial services to households and individuals person often refers as Personal finance. The Personal finance management provides advises related to investment and financial opportunities. It needs to build an efficient personal finance management process for getting the system excellence. Strategies of personal finance are discussed in this paper.
\end{abstract}

Keywords: Managing money, investments, budget, banking, financial opportunities.

\section{INTRODUCTION}

Activities of personal financial like investing, income generation, protection, saving and spending managed and planned by using Personal finance. It can summarize the process of managing the personal finances in a financial plan or budget. Most common and important aspects of financial management are described in this paper.

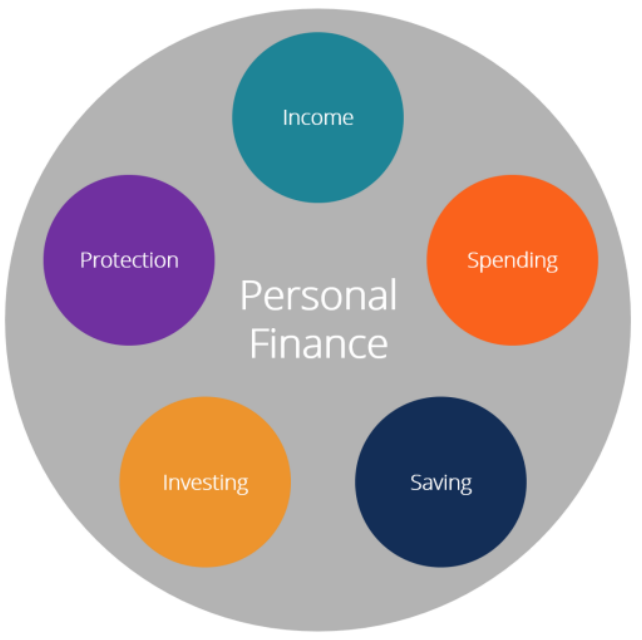

Figure 1: Personal Finance

Revised Version Manuscript Received on 16 September, 2019.

* Correspondence Author

Ridwan, STIE Nobel Indonesia Makassar, Indonesia. E-mail: ridwan@stienobel-indonesia.ac.id

Sukarman, Akademi Teknik dan Keselamatan Penerbangan Makassar, Indonesia.

E. Laxmi Lydia, Professor, Vignan's Institute of Information Technology(A), Department of Computer Science and Engineering, Visakhapatnam, Andhra Pradesh, India. E-mail: elaxmi2002@yahoo.com

K. Shankar, Department of Computer Applications, Alagappa University, India. E-mail: shankarcrypto@gmail.com

Phong Thanh Nguyen*, Department of Project Management, Ho Chi Minh City Open University, Vietnam. E-mail: phong.nt@ou.edu.vn

\section{Personal Finance Areas}

\section{Saving of Money}

For future spending or investing the excess cash can be consider as saving of money. If what the person spend and what he earn as income there is any surplus the difference can be defined as saving or investments. Saving management is the crucial factor of personal finance. Basic types of savings are as follows:

a. Securities related to market of money

b. Cash in Physical form

c. Savings in bank accounts

d. Bank account checking

\section{Income}

A source of cash flow that receive by a person can refers as income, the income are used for supporting family and themselves. Basic types of income are including:
a. Pensions
b. Bonuses
c. Dividends
d. Salaries
e. Hourly wages

\section{Investing}

The purchasing of assets in the hope that it will give more money that previously invested can be consider as investment. It use as an expectation of generate a rate of return. All investment does not give always positive return so investment carries some risks. Some basic types of investing are as follows:
a. Commodities
b. Mutual funds
c. Private companies
d. Stocks
e. Real estate
f. Bonds
g. Art 


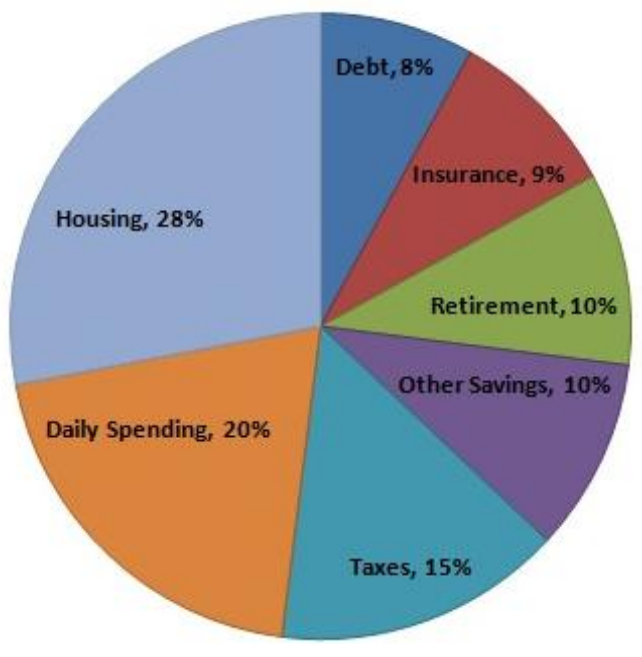

Figure 2: Personal Finanace investements

\section{Protection}

To guard against an adverse or unforeseen event Personal protection refers to a wide range of products. Some basic types of protection products are:

a. Estate planning

b. Life insurance

c. Health insurance

\section{Spending}

Related to buying services and goods or anything consumable things all types of expenses an individual incurs including in appending. All spending divided in two categories: one is credit and other is cash. Some basic types of spending including:
a. Food
b. Taxes
c. Rent
d. Credit card payments
e. Mortgage payments
f. Travel
g. Entertainment

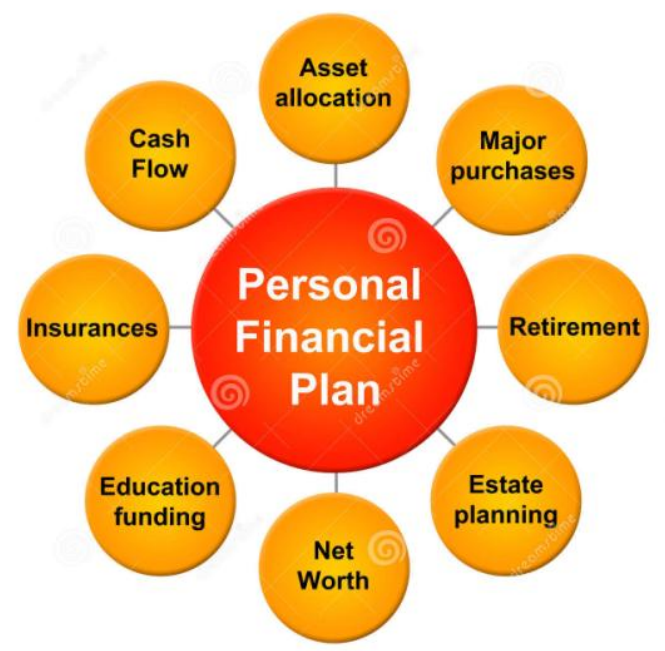

Figure 3: Types of Personal Financial Plan

\section{THE PROCESS OF PERSONAL FINANCE PLANNING}

Good financial management comes down to having a strong arrangement and adhering to it. The majority of the above regions of individual fund can be wrapped into a spending limit or a formal monetary arrangement. These plans are usually arranged by close to home investors and speculation counsels who work with their customers to comprehend their needs and objectives and build up a suitable strategy.

The steps of process of financial planning are as follows:

1. Defining Goals

2. Development of plan

3. Assessment

4. Execution of process

5. Reassessment and Monitoring

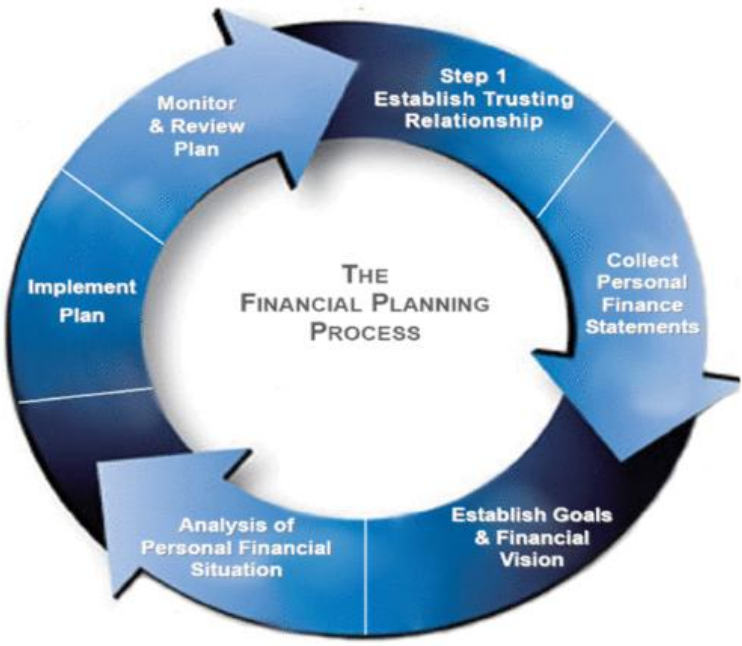

Figure 4: Steps of Personal Financial Process

\section{CATEGORIES OF PERSONAL FINANCE}

The categories of personal finance are given below:

1. People: It most likely wouldn't consider individuals a class of individual money. In any case, you would absolutely concur that you have sentiments about cash and connections have a cash segment. So the "individuals" classification is twofold: 1) it's cash diagram and 2) it's the manner by which identify with others with regards to cash.

2. Income Streams: An Income stream is cash that it makes during the month. It's cash coming in. Any income that get is viewed as a pay stream. The more income streams it have, the better.

3. Debt: It will experience considerable difficulties building riches on the off chance that remain owing debtors particularly shopper obligation. Obligation can be a device to push openings But purchasing a home with obligation will really not make rich by any stretch of the imagination - it simply will offer the chance to be a property holder.

4. Money Management: Money Management is the means by which you deal with the cash you have. It's the sparing, contributing, spending, and monetary objective setting that you do throughout the entire year. 
5. Career: What it accomplishes for "normal everyday employment" is the work classification. This is the profession, where a great many people invest their energy for cash. The vast majority will always remember about this classification.
6. Savings: Saving cash is its very own class (particular from by and large cash the executives and contributing). Setting aside cash implies the cash that you keep in the bank that is fluid.

\section{Investments}

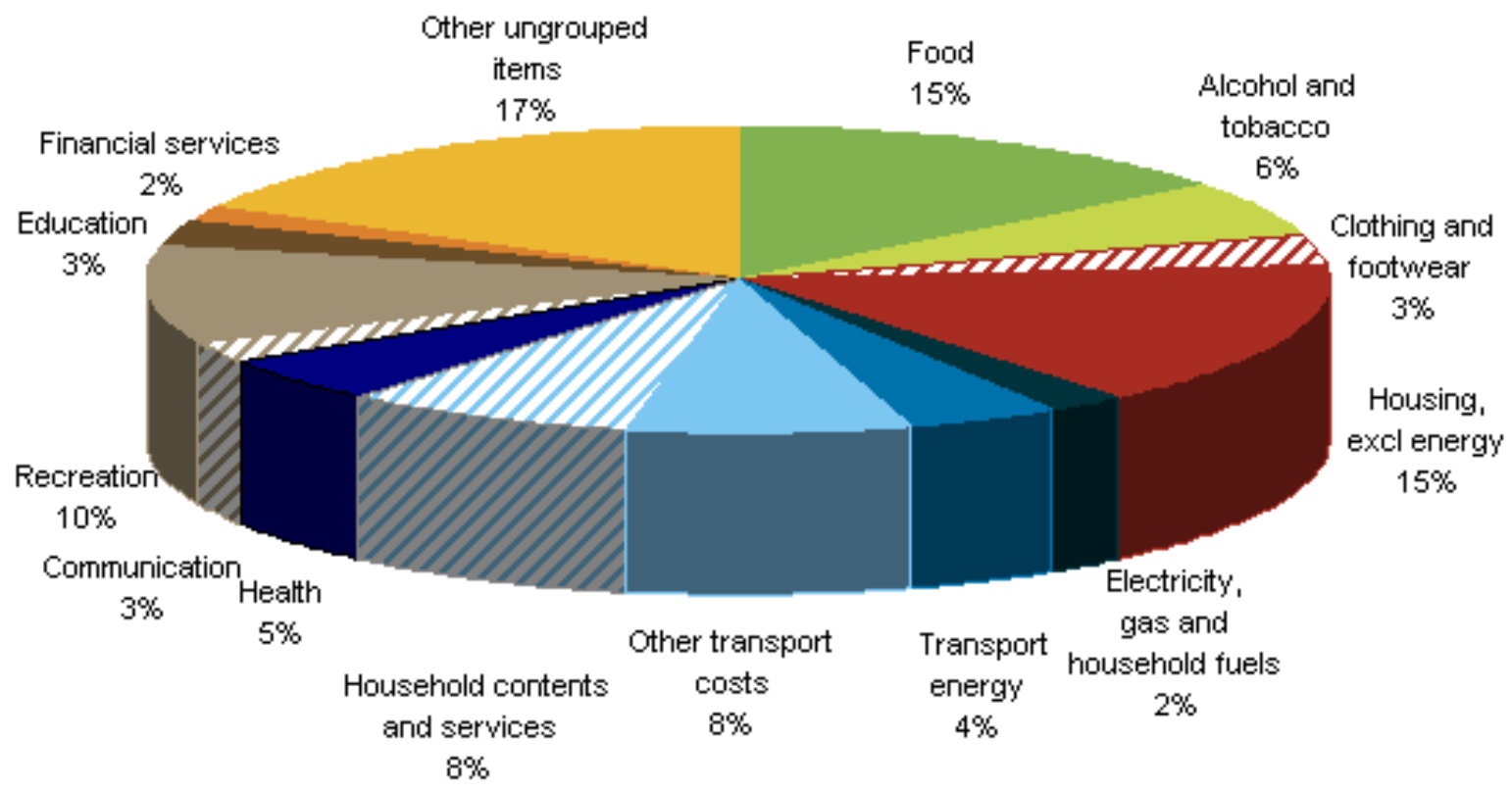

Figure 5: Sepnding of personal Finance

7. Material Things: Suze Orman consistently says "individuals first, at that point cash, at that point things." This classification is the "things" in her statement. Things meaning way of life. It's the way of life that will significantly influence the capacity to construct riches.

8. Wealth Building or wealth Investing: Wealth building is unique in relation to setting aside cash. The reason for riches building is to expand your total assets and increment your salary.

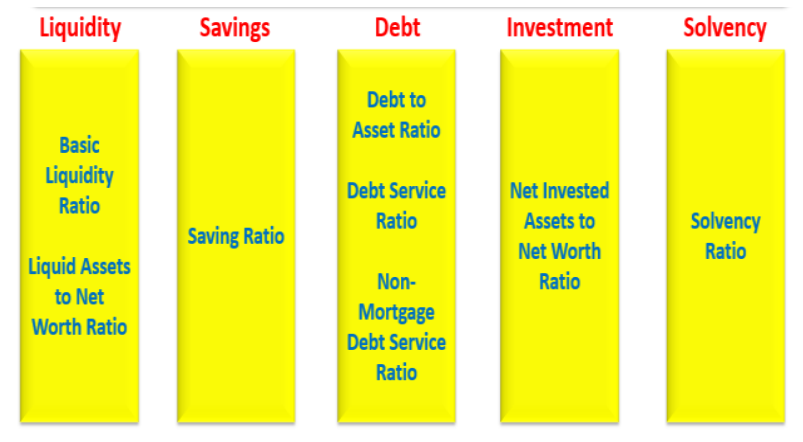

Figure 6: Categories of Personal Finance

\section{KEYS TO SUCCESSFULLY MANAGING PERSONAL FINANCES}

For improving the condition of money it can do some common things. For managing the personal finances successfully some steps are given as follows:

1. Make and Stick to a Budget: Budget is probably the greatest instrument that will help succeed monetarily. It permits to make a spending plan so it can allot your cash such that will arrive at your objectives.

2. Detail Financial Goals: Take some an opportunity to compose explicit, long haul budgetary objectives. It might need to take a month-long outing to Europe, purchase a venture property, or resign early. These objectives will influence how it plan funds.

3. Don't Be Afraid to Ask for Advice: Advice: Once it have developed reserve funds and need to start contributing to build riches, address a budgetary organizer to settle on shrewd venture choices

4. Pay Off Debt: Debt is a gigantic snag for some with regards to arriving at money related objectives. That is the reason it should make killing it a need. Set up an obligation end plan, to help pay it off more rapidly.

5. Flesh Out it Plan: A money related arrangement is significant in helping you arrive at your budgetary objectives. The arrangement ought to have numerous means or achievements. An example plan may incorporate making a month to month spending plan and spending plan, at that point escaping obligation.

\section{CONCLUSION}

Managing the money, saving and investing terms are come in to Personal finance. The term Personal finance includes mortgages, estate planning, investments, budgeting, insurance, banking and tax planning. It can summarize the process of managing the personal finances in a financial plan or budget. 


\section{REFERENCES}

1. Tahira, K. Hira (1 December 2009). "Personal finance: Past, present, and future". Social Science Research Network. Iowa State University Department of Human Development and Family Studies: 4-16.

2. "Guide to the Margaret G. Reid Papers 1904-1990". The University of Chicago Library. 2010. Archived from the original on 3 July 2013. Retrieved 28 September 2015.

3. Ariely, Dan (July 2009). "The End of Rational Economics". Harvard Business Review. Retrieved 28 September 2015.

4. "Financial Planning Curriculum Framework". Financial Planning Standards Board. 2011. Archived from the original on 1 February 2012. Retrieved 7 April 2012.

5. Chienwattanasook, K., Wattanapongphasuk, W., Prianto, A., \& Jermsittiparsert, K. 2019. "Corporate Entrepreneurship and Business Performance of Logistic Companies in Indonesia." Industrial Engineering \& Management Systems 18 (3): 538-547.

6. Dawabsheh, M., Hussein, A., \& Jermsittiparsert, K. 2019. "The Triangular Relationship between TQM, Organizational Excellence and Organizational Performance: A Case of Arab American University Palestine.” Management Science Letters 9 (6): 921-932.

7. Jermsittiparsert, K., Siam, M., Issa, M., Ahmed, U., \& Pahi, M. 2019. "Do Consumers Expect Companies to Be Socially Responsible? The Impact of Corporate Social Responsibility on Buying Behavior.' Uncertain Supply Chain Management 7 (4): 741-752.

8. Syazali, M., Putra, F., Rinaldi, A., Utami, L., Widayanti, Umam, R., \& Jermsittiparsert, K. 2019. "Partial Correlation Analysis Using Multiple Linear Regression: Impact on Business Environment of Digital Marketing Interest in the Era of Industrial Revolution 4.0." Management Science Letters 9 (11): 1875-1886.

9. Sae-Lim, P. \& Jermsittiparsert, K. 2019. "Is the Fourth Industrial Revolution a Panacea? Risks toward the Fourth Industrial Revolution: Evidence in the Thai Economy." International Journal of Innovation, Creativity and Change 5 (2): 732-752.

10. Chatchawanchanchanakij, P., Arpornpisal, C., \& Jermsittiparsert, K. 2019. "The Role of Corporate Governance in Creating a Capable Supply Chain: A Case of Indonesian Tin Industry." International Journal of Supply Chain Management 8 (3): 854-864.

11. Hartinah, S., Suharso, P., Umam, R., Syazali, M., Lestari, B., Roslina, R., \& Jermsittiparsert, K. 2020. "Teacher's Performance Management: The Role of Principal's Leadership, Work Environment and Motivation in Tegal City, Indonesia." Management Science Letters 10 (1): 235-246

12. Haseeb, M., Hussain, H., Slusarczyk, B., \& Jermsittiparsert, K. 2019. "Industry 4.0: A Solution towards Technology Challenges of Sustainable Business Performance." Social Sciences 8 (5): 184.

13. Haseeb, M., Hussain, H., Kot, S., Androniceanu, A., \& Jermsittiparsert, K. 2019. "Role of Social and Technological Challenges in Achieving a Sustainable Competitive Advantage and Sustainable Business Performance.” Sustainability 11 (14): 3811.

14. Haseeb, M., Kot, S., Hussain, H., \& Jermsittiparsert, K. 2019. "Impact of Economic Growth, Environmental Pollution, and Energy Consumption on Health Expenditure and R and D Expenditure of ASEAN Countries." Energies 12 (19): 3598.

15. Huda, S., Tsani, I., Syazali, M., Umam, R., \& Jermsittiparsert, K. 2020. "The Management of Educational System Using Three Law Auguste Comte: A Case of Islamic Schools." Management Science Letters 10 (3) (In press), DOI: 10.5267/j.ms1.2019.9.018.

16. Usak, M., Kubiatko, M., Shabbir, M., Dudnik, O., Jermsittiparsert, K., \& Rajabion, L. 2019. "Health Care Service Delivery Based on the Internet of Things: A Systematic and Comprehensive Study." International Journal of Communication Systems 32 (14): e4179.

17. Jermsittiparsert, K., Ambarita, D., Mihardjo, L., \& Ghani, E. 2019. "Risk-Return through Financial Ratios as Determinants of Stock Price: A Study from ASEAN Region.” Journal of Security and Sustainability Issues 9 (1): 199-210.

18. Thabhiranrak, T. \& Jermsittiparsert, K. 2019. "Towards Sustainable Functioning of Organization: Women Empowernment and Corporate Management Culture." Journal of Security and Sustainability Issues 9 (1): 321-332.

19. Chienwattanasook, K. \& Jermsittiparsert, K. 2019. "Impact of Entrepreneur Education on Entrepreneurial Self-Employment: A Case Study from Thailand." Polish Journal of Management Studies 19 (1) 106-116.

20. Jermsittiparsert, K., Sutduean, J., Sriyakul, T., \& Khumboon, R. 2019. "The Role of Customer Responsiveness in Improving the External Performance of an Agile Supply Chain." Polish Journal of Management Studies 19 (2): 206-217.
21. Jermsittiparsert, K., Sutduean, J., \& Sriyakul, T. 2019. "Effect of Service Innovation and Market Intelligence on Supply Chain Performance in Indonesian Fishing Industry." Industrial Engineering \& Management Systems 18 (3): 408-417.

22. Jermsittiparsert, K., Namdej, P., \& Somjai, S. 2019. "Green Supply Chain Practices and Sustainable Performance: Moderating Role of Total Quality Management Practices in Electronic Industry of Thailand." International Journal of Supply Chain Management 8 (3): 33-46.

23. Somjai, S. \& Jermsittiparsert, K. 2019. "The Trade-off between Cost and Environmental Performance in the Presence of Sustainable Supply Chain." International Journal of Supply Chain Management 8 (4): 237-247.

24. Jermsittiparsert, K. \& Sawasdee, A. 2012. "Formal Education for Non-Thai or Undocumented Person in Thailand amidst the Challenge of Nationalism and Transnationalism: A Case Study of Wat Sirimongkhol School, Samut Sakhon Province.” Kasetsart Journal Social Sciences 33 (2): 203-213.

25. Kadlec, Dan (10 October 2013). "Why We Want-But Can't Have-Personal Finance in Schools". Time. Retrieved 24 October 2015.

26. Antonia, Farzan (2 May 2015). "High schools are beginning to require personal finance courses. Finally". Business Insider. Archived from the original on 28 September 2015. Retrieved 28 September 2015.

27. Behrman, Jere R., Mitchell, Olivia S., Soo, Cindy K. and Bravo, D. (2011): "How Financial Literacy Affects Household Wealth Accumulation," 2012 AER Papers and Proceedings.

28. Calderon. M, (2014): "The Role of Financial Literacy and of Financial Education intervention in developing countries," DIW Roundup \#34, DIW Berlin.

29. Engelbrecht, L. K. (2011): "The Global Financial Crisis: Response of Social Workers to the Financial Capability of Vulnerable Households in South Africa," Journal of Social Intervention: Theory and Practice, Volume 20, Issue 2, pp. 41-53,

30. Gine, X., Karlan, D., \& Ngatia, M. (2014): "Social Network, Financial Literacy and Index Insurance: Evidences from a Randomized Experiment in Kenya," Edited By Mattias Lundberg and Florentina Mulaj, Enhancing Financial Capability and Behavior in Low and Middle-Income Countries, PP.196-208, , The World Bank, Washington D.C.

31. Ibrahim. E \&. Alqaydi. F., (2013): "Financial Literacy, Personal Financial Attitude, and Forms of Personal Debt among Residents of the UAE", International Journal of Economics and Finance Vol. 5 (7); 2013, ISSN 1916-971X E-ISSN 1916-9728, Published by Canadian Center of Science and Education.

32. Lusardi, A. \& Mitchell, O S. (2013): "The Economic Importance of Financial Literacy: Theory and Evidence," Journal of Economic Literature, Vol. 52(1), P. 5-44.

33. Oanea, D. \& Dornean, A. (2012): "Defining and Measuring Financial Literacy: New Evidence from Romanian' Students of the Master in Finance," Scientific Annals of the Alexandru Ioan Cuza University of Iaşi Economic Sciences, Vol. 59 (2), pp. 113-129.

34. Santos,E. \& Abreu, M. (2013): "Financial Literacy, Financial Behavior and Individuals' Over-indebtedness," WP 11/2013/DE/UECE, School of Economics and Management, Technical University of Lisbon.

35. Shankari, S., Navarathinam, K., \& Suganya, R. (2014): "Financial Literacy towards Banking Products and Services: A survey," International Journal of Management Research and Review, IJMRR/ March 2014/ Volume 4 (3)/Article No-10/396-402, PP.396-402.

36. Wise, S. (2013). The Impact of financial Literacy on New Venture Survival, International Journal of Business and Management, Vol. 8, No. 23. PP. 30 -39, Canadian Center of Science and Education. 